\title{
ECOTOURISM PLANNING IN A WETLAND OF INTERNATIONAL IMPORTANCE AND SUSTAINABLE TERRITORIAL DEVELOPMENT
}

\author{
Dolana Simona ${ }^{1}$ \\ School of Urban Planning, 'Ion Mincu' University of Architecture and Urban \\ Planning, Bucharest (ROMANIA) \\ simonadolana28 [at] gmail.com
}

\begin{abstract}
Wetlands are complex ecosystems, which provide excellent conditions as habitats for numerous species. It has been known that continuous unsustainable urbanization negatively affects natural resources, especially wetlands. The study has underlined the need for proper planning in a wetland of international importance, as a key element in the development of a sustainable urban-rural scenario. This paper is a mixture of both inductive and deductive steps, which underline a case study based on the abductive method. The investigation consisted in analysing the ecotourism planning methods of several case studies and drawing a parallel between them and the study area, Old Danube-Măcin Arm, where this activity is not implemented. The key results show that ecotourism plays a crucial role in the sustainable development of an urban-rural area with the following properties: compact microregion and the adaptability of it to the challenges of the territory. Successful zoning and visitor management methods are used to mitigate the existing conflict between conservation of sensitive areas and the danger of exposing said areas to public use. Ecotourism, encouraged and managed by the community, becomes a way of consolidating the economic growth of the study area.
\end{abstract}

Keywords: Ecotourism, Wetland, Urban, Rural, Sustainable Development.

\section{INTRODUCTION}

Dobrogea, as a region characterized by a long and tumultuous history ${ }^{1}$, offers Romanian civilization a special configuration [1]. The provincial-roman influence is highly visible on the Danube axis, but the high roman-byzantine gradient ${ }^{2}$ highlights Hârșova-Brăila-Galați-Măcin area [2]. Old Danube-Măcin Arm has experienced significant socioeconomic dynamics and land use change, so we are currently facing a problem: an untapped potential of a micro reservation.

\footnotetext{
${ }^{1}$ In the $16^{\text {th }}$ century, the demographics of Dobrogea alters significantly due to military garrisoning of the Ottoman conquerors and the moving of the local population to more secure places focusing especially on the Danube. The villages are abandoned, as evidenced by the toponymic duplications of settlements on both sides of the Danube. In the $19^{\text {th }}$ century, thanks to ties with the Principalities, Transylvania and then with Romania, the Romanian population in Dobrogea grew considerably, and the human flux continued steadily in both directions. The post-war agrarian reforms found the agricultural population much diminished.

${ }^{2}$ The differentiated proportion of the Roman-Byzantine presence creates in a wider context, regional characteristics.
} 


\section{\#3/2018 URBAN CHALLENGES}

This wetland has the potential to become an attractive destination for tourists, so in these circumstances, the paper aims to present a solution to the problem, through the extensive investigation of the planning methods in different protected wetlands. In addition, by formulating recommendations, the present study can stimulate the debate on ecotourism planning in the study area.

The paper is organized as follows: the first section is the introduction to the study area; the second section presents the methodology used in the research; a third section reports the results and the discussion of the case studies and finally, the last section concludes with some recommendations for the study area.

\subsection{Old Danube-Măcin Arm, between Continuity and Fragmentation}

The study area $(26,792 \mathrm{ha}$, of which 2,889 ha represent the surface of the water) is situated in the south-east region, in Brăila, Constanța and Tulcea counties. It is located near the towns of Brăila, Galați and Hârșova and another protected wetland of international importance: Small Island of Brăila (17,586 ha) and Canaralele of Hârșova (7,406 ha).

Historical analysis of the area has identified both negative aspects such as the late introduction of education, as evidenced by the absence of printing houses or bookstores ${ }^{3}$ in Dobrogea, requiring the books to be brought from the left side of the Danube [3], as well as positive aspects such as the potential of cerealcommercial fairs, as a social meeting place ${ }^{4}$ for the Romanians north and south of the Danube [4]. Another positive aspect is the placement of ports in a commercial transit area, ${ }^{5}$ where the port of Măcin was productive [5].

Today, the area is characterized by a mosaic landscape type, biodiversity, including unique biotopes and natural monuments, as well as important areas of concentration of built heritage. The area is located along an important migration corridor, so it is important for breeding and nesting of rare and very rare bird species. The landscape is specific to meadows, with lakes between sand dunes, marshes, wetlands dominated by shrubs, fishing lakes, islands, canals and drainage channels that create the right conditions for a great biodiversity. The distribution of protected areas in the territory is the following: special protection areas for avifauna (SPA) identified in Smîrdan, Jijila, Măcin, Luncăvița, Greci and Casimcea territorial administrative units; sites of community importance (SCI) in all territorial-administrative units along the Old Danube-Măcin Arm; special areas of conservation (SAC) located only in Măcin and Cerna territorial administrative units.

\footnotetext{
${ }^{3}$ In 1871 a girl school was established in the town of Măcin.

${ }^{4}$ The economic potential of Dobrogea was important, towards the mouth of the Danube River, where urban centres had an important economic role in both transit and local trade. The merchants from different cities like Brăila, Galați, Călărași and Bucharest came to the Dobrogea fairs, where they "channelled all the creative energies" [4].

${ }^{5}$ In the Middle Ages, it was an important transit point for goods from the Principalities, which were directed to the Ottoman markets. By the end of the $18^{\text {th }}$ and early $19^{\text {th }}$ centuries, there are mentions of the commercial trade in this area, grain and wood, products that took the road to Constantinople. After the independence war, there is an important traffic of goods and passengers. In the post-war period, the construction of an industrial platform and the exploitation of construction rocks in Măcin's quarries also favoured the development of the port.
} 
Old Danube-Măcin Arm area has three natural reserves, designated in 2004: Traian Lake, Peceneaga Reserve and Măgurele Reserve. The Peceneaga Reservation is recognized for the contrasting landscape features ranging between the very old rocks of Dobrogea and the new sediments of the Danube. Traian Lake is very important for the protection of bird species, while the Măgurele reserve has an important population of Euphorbia myrsinites. ${ }^{6}$ The altitudes range from 0 meters near the Danube, up to 198 meters on the hills of the Dobrogea region. Terraces only exist on the left side of the Danube.

The activities carried out in the protected wetland are agriculture, forestry and fishing and in its surroundings agriculture and forestry. Factors (past, present or future) that negatively affect the environmental nature of the natural corridor are changes in land use (including water surface) and development projects within Ramsar area: hunting, poaching, grazing, urbanization and wind turbines [6]. A relevant aspect of this study is that the area is visited for sport fishing (on the territory of the Smîrdan, Măcin, Carcaliu, Turcoaia, Peceneaga, Ostrov administrative units) but unfortunately, specific tourist infrastructure is nonexistent. $^{7}$ The only tourist capacity is located in the vicinity of the area (Galați, Vădeni, Brăila, Cazasu, Chișcani, Tichilești administrative units) [7], but are not well connected with the study area. Other important issues are that the area is characterized by a low living standard, low percentage of the active population and the migration of trained young people to the urban centres.

The study area is rich in historical monuments. In the following territorial administrative units there are monuments of national importance (category I and IV): Smîrdan (Obelisk of the soldiers in War of Independence), Jijila (romanbyzantine fortress and archaeological site), Măcin (Arrubium fortress, Muslim cemetery and Roman necropolis), Turcoaia (Troesmis fortress complex and medieval settlement), Ostrov (Beroe fortress and necropolis) and Luncăvița (fortified settlement). There are also many monuments of local interest (category I and II) in the following territorial administrative units: Jijila (Getic settlement), Luncăvița (Getic settlement, archaeological site and Roman-byzantine settlement), Carcaliu (archaeological site and Eneolithic settlement), Hamcearca (fortified settlement), Cerna (Traian archaeological site and Roman and Neolithic settlement), Peceneaga (fortification, archaeological site, Roman and Neolithic settlement), Topolog (Roman and Neolithic settlement, archaeological site and Getic settlement) and Casimcea (archaeological site, Roman and Neolithic settlement)[8].

The area is also rich in art and folk traditions ${ }^{8}$ identified in all the territorial administrative units. The most interesting are the manufacture of popular crafts (e.g. knitted rope) and the habits of the Lipovan Russians [9].

Even if there are many natural resources and a rich building heritage with potential for the sustainable development, no management plan for the study area has been identified. Some information on the development of tourism has been found in

\footnotetext{
${ }^{6}$ Scientific name of a plant, which is part of the upper Euphorbia class.

7 No information on the existing tourist accommodation was found on the website of the National Institute of Statistics.

8 Such as "Paparuda" tradition in Luncăvița, Jijila and Măcin. Other traditions identified in the area:

"Lăzărelul", "Olaria", "Caloianul", "Oleleul" (Măcin), "Moșoaiele" (Luncăvița).
} 


\section{\#3/2018 URBAN CHALLENGES}

some documentation, such as the FLAG Integrated Local Development Strategy Old Danube-Măcin Arm [10].

The above information leads to the importance of proper wetland planning so as to support the working hypothesis, that ecotourism will positively influence the behaviour of local communities. If ecotourism influences the behaviour of local communities, then the areas where ecotourism activities are implemented will have lower urbanization rates in the near future than protected areas which do not benefit from ecotourism activities.

The objective of this paper is to show that ecotourism is an appropriate choice for the study area.

\section{METHODOLOGICAL ASPECTS}

\subsection{Research Strategy}

Can ecotourism be implemented in the study area to change its economy and the quality of life? Starting from this research question, the present paper identifies the following strategic steps:

1. The visualisation of the negative and positive aspects of ecotourism implemented in other protected wetlands and the motivations of an ecotourist to choose these areas as a destination;

2. The understanding the ecotourism planning process and its instruments.

Knowing these aspects, emerges the possibility of adopting ecotourism as an instrument for the sustainable development of the study area.

\subsection{The Data Collection Instrument}

Since no such research has been carried out on the study area, Old Danube-Măcin Arm, it was necessary to use the qualitative research approach, using an abductive method with an inductive tendency. Various documents were consulted to understand the ecotourism activity, its effects and planning process. Several case studies have been chosen to match the study area, thus understanding the way in which similar areas have developed.

\subsection{Data Processing and Interpretation}

As the paper focuses on the understanding of ecotourism planning in a wetland, as a tool for sustainable urban and rural development, the data consists in synthesizing the relevant information for the study area.

\section{RESULTS AND DISCUSSION}

\subsection{Ecotourism, Positive and Negative Aspects}

Numerous studies have demonstrated the benefits of implementing ecotourism in a protected area. First of all, the development of it requires intersectoral 


\section{\#3/2018 URBAN CHALLENGES}

involvement, a multidisciplinary approach [11]. Also, the availability of resources in a territory, factors such as climate, season, accessibility and the attitude of the host community [12] are motivations of an ecotourist to choose a destination ( $c$. Table 1). Ecotourism is the ideal instrument for strengthening cooperation between communities in the area by providing a socio-economic improvement. Cultural and historical attractions, such as traditional architecture, play a crucial role in the attraction of the ecotourists [13]. Instead, some studies have also suggested negative aspects of ecotourism, such as environmental pollution, ecosystem degradation and reduced environmental aesthetic [14]. The increased number of ecotourists can generate severe environmental problems, especially in very fragile areas of the ecosystem (e.g. excessive disturbance of breeding bird populations) [15].

Motivation
Desire to visit new destinations
Spend time with family, friends
Contact with nature
Disconnect from routine
Accesible ecotourist destination
Search of tranquility
Fame and reputation of the ecotourist destination
Sports
Taste the gastronomy
Shop handcrafts

Table 1: Example. The most common motivations for the visit, identified in the examples

Source: The author.

\subsection{The Ecotourism Planning Tool}

As shown above, ecotourism is a complex activity in permanent interaction with economic, psychological, social and cultural factors. It has seen the fastest development in the global tourism sector, so it is necessary to develop a model for reducing the environmental impact and to create a level of development that satisfies the needs of both ecotourists and the community of the studied area in a sustainable manner. The explorations of the microregional gradient ${ }^{9}$ (cf. Table 2)

\footnotetext{
${ }^{9}$ The gradient concept is defined as the degree of change of the properties of a particular phenomenon relative to a particular direction, an idea described by Frankhauser [16]. In the present paper, the gradient is identified by two dimensions: the population density and the distance between rural settlements and the most important urban centre.
} 


\section{\#3/2018 URBAN CHALLENGES}

are suitable for this purpose [16]. Applying the microregional gradient as a tool for creating a future scenario, analysed using the following indicators: ecosystem services indicators (e.g. habitat quality, food supply, food productivity, and energy supply), socio-economic indicators (e.g. road density, urban fabric, population density, household size, housing area). This model hypothesizes the behaviour of the ecotourists and those of the area's inhabitants. If the availability of wetland data is limited, it is necessary to use variables in the next stages of the process. Specifically, it is necessary to quantify the economic values of the factors that characterize urban areas. Also, variables need to be analysed, for example land use patterns and flood risks. Sustainability, adaptability to risk and compromises between risks and other factors should be considered.

\begin{tabular}{|c|c|c|c|c|}
\hline Landscape metrics & Description & Unit & Rural & Urban \\
\hline Area & Absolute size of wetland & $\mathrm{m}^{2}$ & & \\
\hline Perimeter & Length of the bordeline of a wetland & $\mathrm{m}$ & & \\
\hline Number of patches & $\begin{array}{l}\text { Number of all habitat and land-use patches } \\
\text { in a wetland based on subunits }\end{array}$ & - & & \\
\hline Mean patch size & $\begin{array}{l}\text { Mean size of all habitat and land-use } \\
\text { patches in a wetland based on subunits }\end{array}$ & $\mathrm{m}^{2}$ & & \\
\hline Mean perimeter to area ratio & $\begin{array}{l}\text { Mean ratio of patch-borderline lenght to } \\
\text { patch size of all habitat and land-use } \\
\text { patches in a wetland based on subunits }\end{array}$ & $\mathrm{m}^{-1}$ & & \\
\hline Distance to nearest neighbour & $\begin{array}{l}\text { Shortest distance between two adjacent } \\
\text { protected areas, measured from edge to } \\
\text { edge }\end{array}$ & $\mathrm{m}$ & & \\
\hline Mean distance to nearest similar habitat & $\begin{array}{l}\text { Mean distance of all habitat and land-use } \\
\text { patches based on main units which belong } \\
\text { to the land-use type with the highest share } \\
\text { in the size of a protected area to the next } \\
\text { patch of the same landuse type but outside } \\
\text { protected space, measured from edge to } \\
\text { edge }\end{array}$ & $\mathrm{m}$ & & \\
\hline
\end{tabular}

Table 2: Example. Overview of landscape structure metrics on the basis of habitat and land-use types used as explaining variables for species richness in the wetlands

Source: [20].

\subsection{The case of Soomaa National Park, Rivers of the Pärnu River Basin, Estonia}

The most valuable aspect of the Soomaa National Park ${ }^{10}$ is its wilderness. An interesting factor is that the area's community has adapted to the natural conditions. According to the Sustainable tourism development strategy for Soomaa National Park [17], the area is divided into four zones:

- National park territory: sensitive area, the most attractive, it exposes wilderness and nature-friendly lifestyle;

\footnotetext{
${ }^{10}$ In 1997, the second largest park in Estonia, was included in the list of wetlands of the most important nature protection areas in Europe, becoming a Ramsar site.
} 


\section{\#3/2018 URBAN CHALLENGES}

- Other protected areas in the region: small protected areas that depend on the national park, where tourism is diminished;

- The immediate surroundings of the national park: businesses are favoured and the municipality provides the necessary assistance services;

- Outside of the national park: connects to larger city areas, main roads, opportunities for less sustainable businesses.

The immediate surroundings of the national park are more detailed and therefore, additional areas are created, depending on the sensitivity of the area:

- The taboo areas of the local community;

- Areas of impacts of tourist objectives;

- The impact areas of waterways;

- Areas that should be visited with a guide;

- Areas with a limited number of visitors;

- Restricted areas.

The aim of zoning is to avoid or minimize the negative impact of ecotourism and to increase the positive impact. Therefore, successful zoning and visitor management methods are used as a management instrument to help solve the existing conflict between conservation of sensitive areas and places of public use. Ecotourism creates a good balance between conservation objectives and the development of the area.

\subsection{The case of Lonjsko Polje Nature Park, the Sava River, Croatia}

The Sava River is recognized for the conservation of natural resources as well as for the significant socio-economic impact on cross-border regional development, due to the connection with three European capitals: Ljubljana, Zagreb and Belgrade. The management of the Sava's natural resources is based mostly on the management of the flood plains. Its flooding is almost completely controlled. The protected wetland Lonjsko Polje ${ }^{11}$ is an important retention area where the activities depend on the regular inflow and outflow of water.

The historical and rural settlements in the surrounding area of Lonjsko Polje Nature Park not only include habitats for many species, but also conserve traditional architecture. In this protected wetland along there has been an increasing trend of the visits in the park, ${ }^{12}$ following the collaboration between eco-tourism and cultural tourism [18]. The main activities carried out in this area are driving a solar boat, canoe safari, biking and bird watching.

According to the Life and Europe's wetlands - Restoring a vital ecosystem, this case study is promoting a wise use approach to the management of the wetland [19]:

- Conserve its natural resources;

\footnotetext{
${ }^{11}$ Located in the floodplains of the middle Sava River Basin, it represents the largest floodplain area of the Danube River catchment. It is both a Ramsar wetland site, an important bird area.

${ }^{12}$ The statistical data shows an increased number of visitors, during the years 2001 and 2008. "The number of visitors increased from 2510 to 21100 and respectively the accommodation provision has increased from 11 to 68 available beds between the years 2005-2008."
} 


\section{\#3/2018 URBAN CHALLENGES}

- Increasing positive effects for the local community;

- Raising public awareness;

- Water management for the whole Sava axis.

\section{CONCLUSIONS AND RECOMMENDATIONS}

This paper presented a brief description of the implementation of ecotourism in a protected wetland area. There are many approaches to the sustainable development of a depopulated territory, however, with these results, the paper answers the research question asked, as follows: Old Danube-Măcin Arm is a protected wetland where ecotourism can be carried out as an economic activity complementary with the tradition of the local community.

At this stage, the paper may formulate directions and recommendations of ecotourism planning in the Old Danube-Măcin Arm area:

1. Promoting the potential of the area: natural (diversified protected areas) and the concentration of the building heritage (numerous historical settlements);

2. Attracting investments;

3. Developing innovative ecotourism attractions and infrastructure.

As it has been disguised in the previous chapter, the determination of the microregional gradient is necessary in this sensitive area. The calculation of relevant indicators is the basis of ecotourism planning. Here, ecotourism would be successful if it were part of a more complex network across the region, linking itself to ecotourism of the Danube Delta. Each element of this system would have little impact on the protected environment, if it were properly planned for the conservation and care of its habitat, in such a manner not to disrupted natural condition of its ecosystems.

The studied area requires zoning, thus establishing different degrees of protection. Firstly, stronger protection measures are required near the Old Danube-Măcin arm, where activities like discovering and exploring the delta's wild landscape, using boats and kayaks, bird watching, and sport fishing (in certain segments) are possible. Also, combining travel on channels and lakes with tourist accommodation can be feasible with local interventions, such as the implementation of floating hotels. However, in this first area there should be sub segments with limited number of visitors and sub segments with restricted visiting.

Secondly, medium protection measures are required in the area of other natural attractions near rural settlements. Here, the following activities may be possible: hiking (the Măcin Mountains), sport fishing (Traian and Iacobdeal lakes), bird watching, photographic safari and visits of ancient settlements that intersect the area.

In the last zone, the activity based on rural ecotourism needs light measures. Its planning and implementation, encouraged and managed by the community, would become a way of consolidating the economic growth of this microregion. The activities that are suitable to this area could be accommodating and guiding ecotourists by the local rural community. In this urbanized cores, traditions and art (gastronomic tourism based on traditional cuisine and crafting) can be combined with the view of the mosaic landscape. 
This paper ends hoping that it may draw more research interest to enhance understanding of the potential of ecotourism implementation in this area of study.

\section{References}

[1] Lazia, L. (1997), "Câteva considerații privind fenomenul antroponimic Dobrogean" ["Some Considerations Concerning the Dobrogean Anthroponomical Phenomenon"], Analele Dobrogei, 3, 1, pp. 57-75.

[2] Paraschiv-Talmațchi, C. (2006-2008), "Geneza ornamenticii ceramice specifică veacurilor VIII-XI, la Dunărea de Jos" ["The Genesis of Ceramic Ornamentation Specific to the $8^{\text {th }}-11^{\text {th }}$ Centuries at the lower Danube"], Analele Dobrogei, 9, pp. 15-27.

[3] Șopu, D. (1999), "Viața culturală a românilor din Dobrogea până la 1878" ["The Cultural Life of Romanians in Dobrogea until $\left.187{ }^{\prime \prime}\right]$, Analele Dobrogei, 5, 2, pp. 268-274.

[4] Ilie, A. (2006-2008), „Panairul de la Medgidia” ["The Fair of Medgidia”], Analele Dobrogei, 9, pp. 77-86.

[5] Borandă, G. (1999), „Porturi dobrogene: Isaccea și Măcin” ["The Ports of Dobrogea: Isaccea and Măcin"], Analele Dobrogei, 5, 2, pp.107-109.

[6] Ramsar Sites Information Service. Information Sheet on Ramsar Wetlands (RIS) (2009-2012). Old Danube-Măcin Arm. Available at: https://rsis.ramsar.org/RISapp/files/RISrep/RO2116RIS.pdf [30.03.2018].

[7] Indicator values TUR102C - Tourist Accommodation Capacity Existence. Available at: http://www.insse.ro/cms [30.03.2018].

[8] List of Historical Monuments (2015). Available at: https://patrimoniu.gov.ro/images/Imi-2015/LMI-TL.pdf [30.03.2018].

[9] Association of Local Action Group on Fisheries Old Danube-Măcin Arm. Available at: http://www.flagbratulmacin.ro/ [30.03.2018].

[10] Local Action Group 'The Măcin Mountains'. Available at: http://www.galmuntiimacinului.ro/wp-content/uploads/2017/02/strategie.pdf [30.03.2018].

[11] Fennell, D. A. (2014), Ecotourism ( $4^{\text {th }}$ Ed.), Routledge, London.

[12] Zhang, J., Inbakaran, R.J. and Jackson, M. (2006), "Understanding Community Attitudes towards Tourism and Host-Guest Interaction in the UrbanRural Border Region", Tourism Geographies, 8, 2, pp. 182-204.

[13] Fennell, D. A. (2002), Needs and Assets. Ecotourism Programme Planning, CABI Publishing, New York (NY), pp. 88-110.

[14] Holden, A. (2009), "An Introduction to Tourism-Environment Relationships", in Hill, J., Gale, T. (Eds.), Ecotourism and Environmental Sustainability. Principles and Practice, Routledge, New York (NY), pp. 17-30.

[15] Neil, J. and Wearing, S. (1999), Ecotourism, Butterworth-Heinemann, Oxford (OX), pp. 21-38. 
[16] Frankhauser, P. (1993), "La fractalite des structures urbaines" [Fractal Aspects of Urban Structures], Economica, Paris, p. 10.

[17] Tooman, H. and Ruukel, A. (2012), "Sustainable Development of a Remote Tourist Destination. The Case of Soomaa National Park, Estonia, in Legrand, W., Simons-Kaufmann, C. and Sloan, P. (Eds.), Sustainable Hospitality and Tourism as Motors for Development, Routledge, Abingdon (OX), pp. 276-295.

[18] Protection of Biodiversity of the Sava River Basin Floodplains. A framework for the development of an eco-tourism strategy along the Sava River. Available at: http://www.savariver.com/results\%20download/Task\%20C\%20\%20Tourism\%20S trategy\%20for\%20the\%20Sava\%20River.pdf [30.03.2018].

[19] European Commission, Environment Directorate-General (2007), Life and Europe's Wetlands - Restoring a Vital Ecosystem. Available at: http://ec.europa.eu/environment/life/publications/lifepublications/lifefocus/docume nts/wetlands.pdf [30.03.2018].

[20] Knapp, S., Kühn, I., Mosbrugger, V. and Klotz, S. (2008), "Do Protected Areas in Urban and Rural Landscapes Differ in Species Diversity?", Biodiversity and Conservation, 17, pp. 1595-1612.

Article distributed under a Creative Commons AttributionNonCommercial-NoDerivatives 4.0 International License (CC BY-NC-ND).

Received: March 30, 2018

Accepted: May 15, 2018. 